\title{
Muhasebe Alanında 2004-2018 Y1llar1 Arasında Hazırlanmış Lisansüstü Tezlerin İncelenmesi
}

\section{A Review of Graduate Theses Prepared in the Field of Accounting Between 2004-2018}

\author{
Berke Koç ${ }^{1}$, Alican Berk Yüncü ${ }^{1}$ \\ 'İstanbul Üniversitesi Sosyal Bilimler Enstitüsü, İșletme Anabilim Dalı, İstanbul, Türkiye \\ ORCID: B.K. 0000-0003-4889-3816; A.B.Y. 0000-0001-9479-9404
}

öz

Bu çalışmada, 2004-2018 yılları arasında İstanbul Üniversitesi Sosyal Bilimler Enstitüsü Muhasebe Bilim Dalında tamamlanmış olan doktora ve yüksek lisans tezleri, bibliyometrik analiz yöntemi kullanılarak, kapsamlı bir şekilde incelenmiştir. Bu bağlamda, bu on beş yılda tamamlanan toplam 106 tez incelenmiştir. Doktora ve yüksek lisans tezlerinin sayıları sırasıyla 43 ve $63^{\prime}$ tür. Bu tezlerin bibliyometrik analizi, tez konuları, tez seviyeleri, tez danışmanlarının unvanları, tez sayfalarının sayısı, tez araştırması ile ilgili sektör, tez yazarlarının cinsiyetleri, araştırma yöntemleri ve kullanılan araştırma türleri gibi kriterlere göre yapılmıştır. Sonuçlar finansal muhasebe alanında en çok çalışmanın Uluslararası Finansal Raporlama Standartları üzerine olduğunu göstermiştir. Araştırmanın ilgi çekici bir başka bulgusu ise yüksek lisans tezlerinde en çok vak’a yöntemine başvurulmasıdır.

Anahtar kelimeler: Muhasebe, yüksek lisans ve doktora tezleri, bibliyometrik analiz

\section{ABSTRACT}

In this study, PhD and master theses completed between the years of 2004-2018 at Istanbul University Social Science Institute Accounting Department were comprehensively examined by using bibliometric analysis method. As such, a total of 106 theses completed during these fifteen years were investigated. The numbers of PhD and master theses are 43 and 63 respectively. Bibliometric analysis of these theses was made based on criteria, such as subjects of thesis, levels of thesis, title of thesis advisors, number of pages in thesis, sector related to thesis research, genders of the thesis writers, research methods, and research types used. The results revealed that most study in the financial accounting field is on International Financial Reporting Standards. Another finding of this research was that case method was the most widely used in master theses.

Keywords: Accounting, master and $\mathrm{PhD}$ thesis, bibliometric analysis

Başvuru/Submitted: 02.12.2019 Revizyon Talebi/Revision Requested: 27.12.2019 Son Revizyon/Last Revision Received: 03.01.2020 Kabul/Accepted: 07.01.2020 Sorumlu yazar/Corresponding author: Berke Koç / berkekoc05@gmail.com

Atıf/Citation: Koc, B. \& Yuncu, A.B. (2020). Muhasebe alanında 2004-2018 yılları arasında hazırlanmış lisansüstü tezlerin incelenmesi. Muhasebe Enstitüsü Dergisi - Journal of Accounting Institute, 62, 63-75. https://doi.org/doi.org/10.26650/MED.2020654140 


\section{Giriş}

Muhasebe, iktisadi birimler olan işletmelerin finansal performansının ölçümü ve gelecekteki durumlarının tahminini amaçlayan bir disiplindir. Muhasebenin tarihi ticaretin tarihi kadar eskidir ancak muhasebenin kuramsal yapısı, çift taraflı kayıt sisteminden çok sonra gelişmeye başlamıştır (Altıntaş 2011). Gittikçe artan küreselleşme, bir bilgi sistemi olan muhasebenin önemi arttırmıştır.

Altıntaş (2011) yine aynı çalışmasında muhasebeyi “İşletmelerde meydana gelen ve parayla ifade edilebilen olayları kayıtlayan, sınıflayan, özetleyen, raporlayan ve ulaştığı sonuçları yorumlayan bir bilgi üretim süreci” olarak tanımlamıştır.

İşletmelerin, yaşamını sürdürebilmesi ve büyümesi için muhasebe bilgi sistemlerinin oldukça iyi olması gerekmektedir. Muhasebe departmanları hatalarla dolu olan bir işletmenin uzun vadede yaşamını sürdürebilmesi mümkün değildir, dolayısıyla muhasebeden sorumlu olan kişiler mesleki yeterliliğe ve deneyime sahip olmalıdır. Bu mesleki yeterliliği sağlayan kaynaklardan biri de akademik yayınlardır. Bu akademik yayınlar özellikle bizim ülkemizde üniversite kaynaklıdır. Üniversitelerin lisansüstü programlarında yürütülen tezler, yürütüldüğü bilim dalına katkı sağlamaktadır.

İşletmeler açısından oldukça önemli olan muhasebe konuları yüksek lisans ve doktora düzeyinde incelenmektedir ve ulaşılan sonuçlar gerçek hayatta dikkate alınmaktadır. Dolayısıyla bu tezlerin içeriğindeki

bilgiler, iyice araştırılmış ve doğru olmalıdır. Bu bilgiler doğrultusunda da objektif ve fayda sağlayan sonuçlar elde edilmelidir. Sonuçların objektif olması ve fayda sağlayabilmesi için uygun bir veri toplama ve istatistiki yönteme ihtiyaç duyulmaktadır. Teorik olarak bir akademik yayın çok iyi olsa dahi eğer uygun bir veri toplama ve istatistiki yöntem seçilmemişse tez sonucunun geçerli olduğu söylenemez. Dolayısıyla tez yazarının tez yazımı boyunca doğru bir şekilde bilgi toplayıp, bu bilgileri veri haline getirip objektif, geçerli ve tutarlı bir sonuca ulaşması gerekmektedir.

Bu çalışmada doğru ve onaylı şekilde sunulan tezler incelenmiştir. İş hayatına da yön veren bu tezlerin bibliyometrik analiz yöntemi kullanılarak hangi muhasebe dallarında, hangi tez konuları, hangi kriterlerle yürütüldüğü incelenmiş ve gelecekte yazılacak tezlerin konuları öngörülmeye çalışılmıştır.

\section{Araştırmanın Amacı ve Yöntemi}

Bu çalışmada İstanbul Üniversitesi Sosyal Bilimler Enstitüsü Muhasebe Bilim Dalında 2004 - 2018 yılları arasında tamamlanmış olan yüksek lisans ve doktora tezlerinin çeşitli kriterler perspektifinden incelenmeye çalışılmış olup, şu şekilde sıralanılabilecek olan sorulara cevap aramak amaçlanmıştır:

1) Toplam kaç tez tamamlanmıştır?

2) Bu tezlerden kaçı yüksek lisans teziyken, kaçı doktora tezidir?

3) Tez sayılarının yıllara ilişkin dağılımı ne şekildedir?

4) Çalışılan tez konuları hangileridir?

5) Tez araştırmaları hangi sektörlerde gerçekleştirilmiştir?

6) Tezler metodolojik anlamda hangi araştırma türü ve yöntemini içermektedirler?

Araştırmanın amacı ve yukarıda cevap aradığı temel sorular bağlamında söz konusu tezler, sayfa sayısı, konusu, araştırmasının yapıldığı sektör, araştırma türleri ve araştırma yöntemleri gibi kriterler açısından bibliyometrik analiz yöntemiyle detaylı bir şekilde araştırılmıştır.

Gerçekleştirilen bu çalışmanın aynı zamanda hem lisansüstü tez danışmanlarına hem de tez konusu belirleme aşamasındaki lisansüstü öğrencilerine, ilgili konuda fikir vererek, fayda sağlaması amaçlanmıştır. 
Bilimsel araştırmaların istatistiki olarak ve nicel şekilde incelenmesinin amaçlandığı analiz yöntemi bibliyometrik analiz olarak adlandırılmaktadır(Pekdemir, Erdoğan, Şen ve Yeke 2015, s. 26). Bu doğrultuda, tezleri incelediğimiz bu çalışmamızda, aşağıdaki kriterlerin incelenmesinin çalışmaya, çalışmadan elde edilecek sonuçlara ve bu sonuçların yorumlanması bağlamında, fayda sağlayacağı düşünülmüştür:

- Tezin Yayınlandığı Y11

- Tezin Konusu

- Tezin Türü (Yüksek Lisans Doktora)

- Tez Danışmanlarının Akademik Unvanları

- Tezlerin Sayfa Sayıları

- Tezlerde Kullanılan Araştırma Tipleri

\section{Araştırmanın Bulguları}

Son 15 yılda Muhasebe Bilim Dalında tamamlanmış lisansüstü tezler incelenmiştir ve bu tezlere ilişkin tanımlayıcı bilgilere, içerik ve metodoloji anlamında çeşitli verilere ulaşılmıştır. Yüksek Öğretim Kurulu Ulusal Tez Merkezi Veri Tabanında İstanbul Üniversitesi Sosyal Bilimler Enstitüsü’nde "Muhasebe" bilim dalı ve "Muhasebe Denetimi” bilim dalında hazırlanmış tezlerin, ilgili zaman dilimine uygun olarak, aratılmasıyla ulaşılan lisansüstü tezleri çalışmanın anakütlesini oluşturmuştur. Toplam 106 yüksek lisans ve doktora tezine ulaşılmıştır.

\subsection{Tanımlayıcı Bulgular}

Tanımlayıcı bilgiler açısından tez sayıları, tez danışmanlarının akademik unvanları ve tezlerin sayfa sayılarına yer verilmiştir.

Bu çalışmada 63'ü yüksek lisans ve 43'ü doktora olmak üzere toplam 106 tez incelenmiştir. Yani 004 ve 2018 yılları arasında yazılmış olan 106 tezin \%59,43'ü yüksek lisans tezi \%40,56’sı ise doktora tezidir. En fazla yüksek lisans tezi 2007 yılında tamamlanmış (11 adet), en çok doktora tezi de 2010 yılında tamamlanmıştır. (7 adet). 2014 yılında ise hiçbir yüksek lisans ve doktora tezi tamamlanmamıştır.

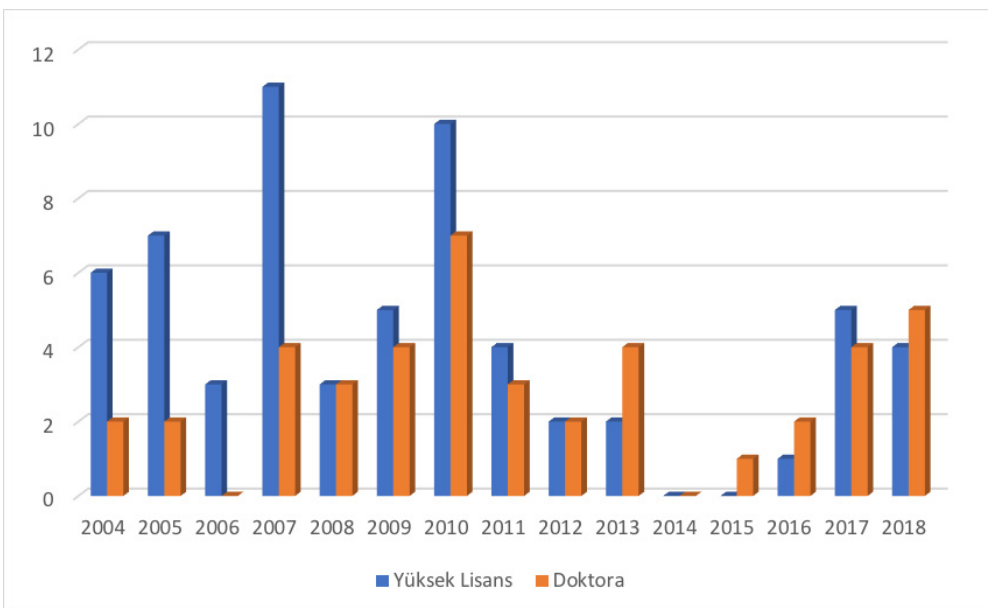

Şekil 1. 2004-2018 Yılları Arasında Yazılmış Tezlerin Yıllara Göre Dă̆ğlımı

Hem yüksek lisans hem de doktora tezlerinin çoğunluğu profesör öğretim üyeleri danışmanlığında yönetilmiştir. Yüksek lisans tezlerinin \%61,90’1 profesörler danışmanlığında yönetilmiştir (Şekil 2). Doktora tezlerinin de \%81,39’u profesörler danışmanlığında yönetilmiştir (Şekil 3). 


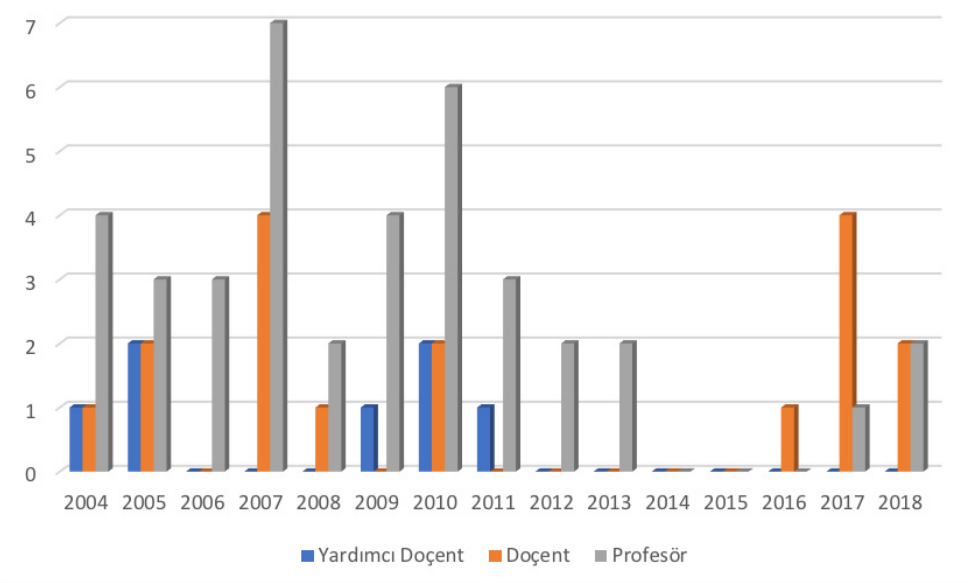

Şekil 2. 2004-2018 Yılları Arasında Yazılmış Yüksek Lisans Tezlerinin Danışman Unvanına Göre Dağılımı

Profesörler danışmanlığında yönetilmiş en fazla yüksek lisans tezi 2007 yllına (7 tane), Doçent öğretim üyelerinin danışmanlığında yönetilmiş en fazla yüksek lisans tezi 2007 ve 2017 yıllarına aittir (4'er tane) (Şekil 2).

Profesörler tarafından yönetilmiş en çok doktora tezi ise 2010 yılına aittir (5 tane) (Şekil 3).

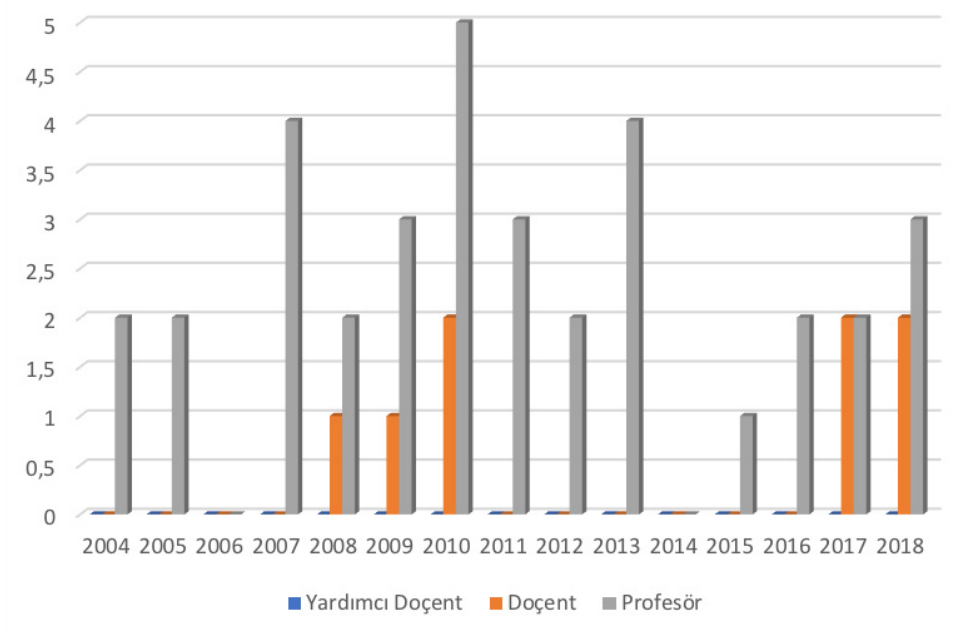

Şekil 3. 2004-2018 Yılları Arasında Yazılmış Doktora Tezlerinin Danışman Unvanına Göre Dağılımı İncelenen 63 yüksek lisans tezinin büyük bir çoğunluğu (35 tanesi) 101-150 sayfa aralığındadır. 13 adedi ise 151-200 sayfa aralı̆̆ında, 9 adedi 200 sayfadan fazla ve 6 adedi de 51-100 sayfa aralı̆̆ındadır (Şekil 4). 


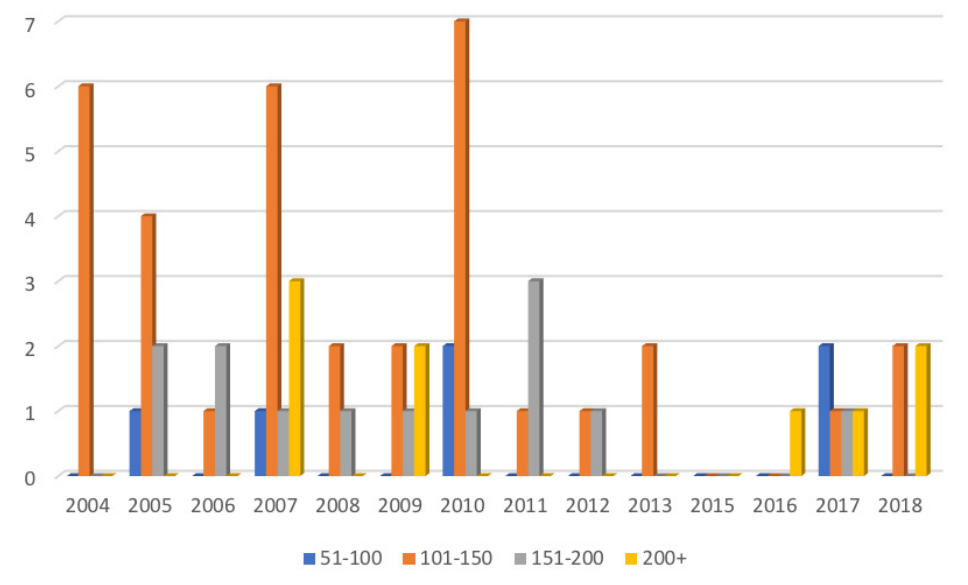

Şekil 4. 2004-2018 Yılları Arasında Yazılmış Yüksek Lisans Tezlerinin Toplam Sayfa Sayılarının Dağılımı

İncelenen 43 doktora tezinden 23’ü 201-300 sayfa aralığında, 10 tez 101-200 sayfa aralığında, 7 tez 301-400 sayfa aralığında ve 3 tez ise 400 sayfadan uzundur (Şekil 5).

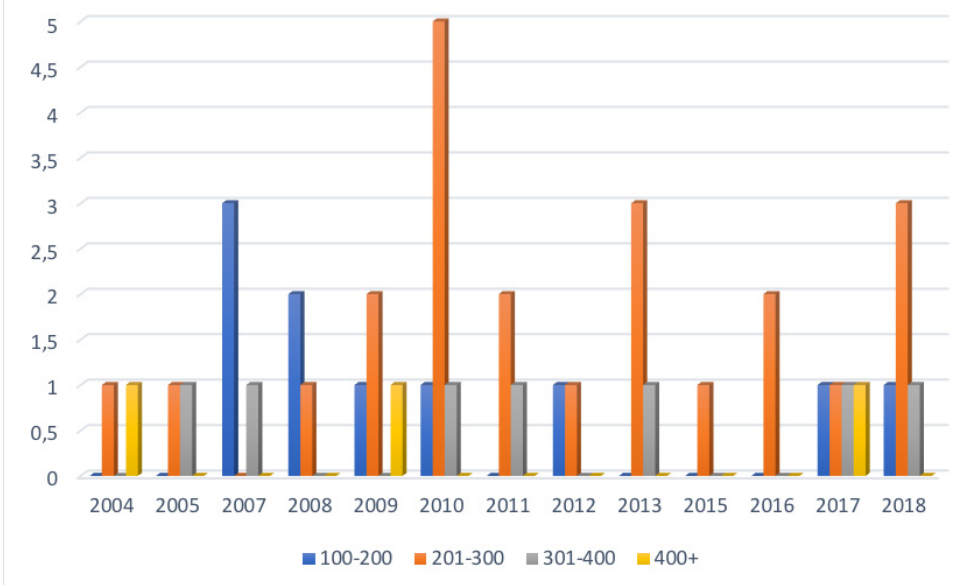

Şekil 5. 2004-2018 Yılları Arasında Yazılmış Doktora Tezlerinin Toplam Sayfa Sayılarının Dağılımı

Yüksek lisans tezlerinin ortalama sayfa sayısı 156, doktora tezlerinin ise ortalama sayfa sayısı ise 256'dır (Şekil 6). 


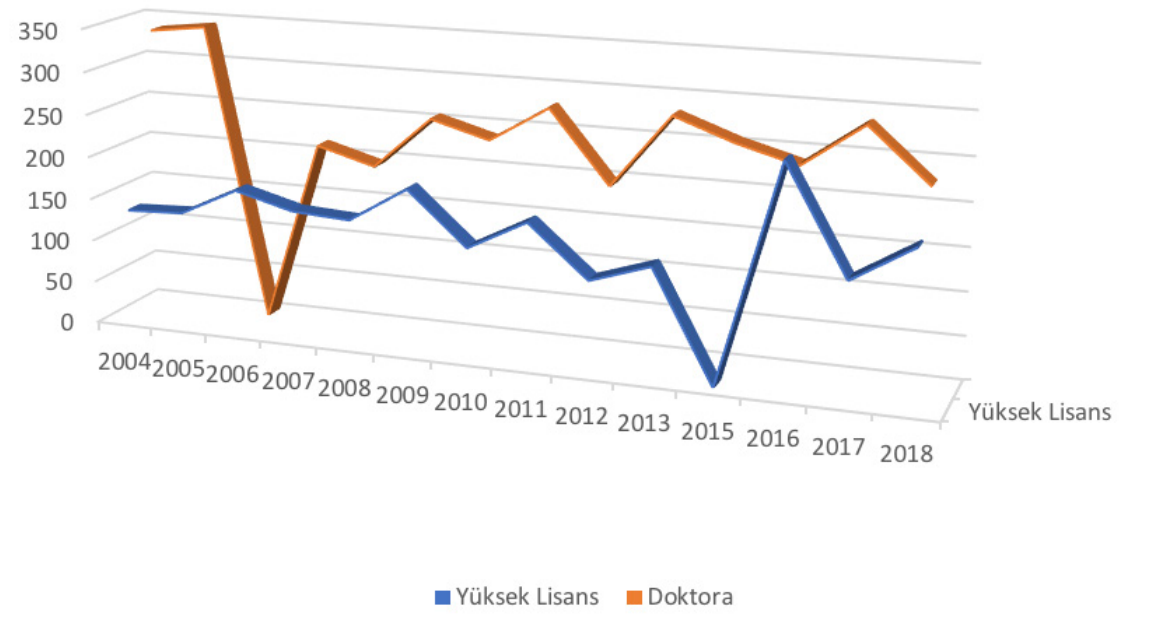

Şekil 6. 2004-2018 Yılları Arasında Yazılmış Yüksek Lisans ve Doktora Tezlerinin Toplam Sayfa Sayıları Ortalamasının Dağılımı

\section{2. İçerik Açısından Bulgular}

İncelenen lisansüstü tezlerde görüldüğü üzere finansal muhasebe, denetim, maliyet muhasebesi, vergi ve finansal kurumlar muhasebesi gibi konular çoğunlukla incelenmiş olan ortak konulardandı (Şekil 7). İncelenen 106 lisansüstü tezlerin 28'inin konusu finansal muhasebe, 22'sinin konusu ise denetimdir. 18 lisansüstü tezin konusu maliyet muhasebesiyken; 12 tezde vergi, 11 tezde ise finansal kurumlar muhasebesi konusu işlenmiştir.

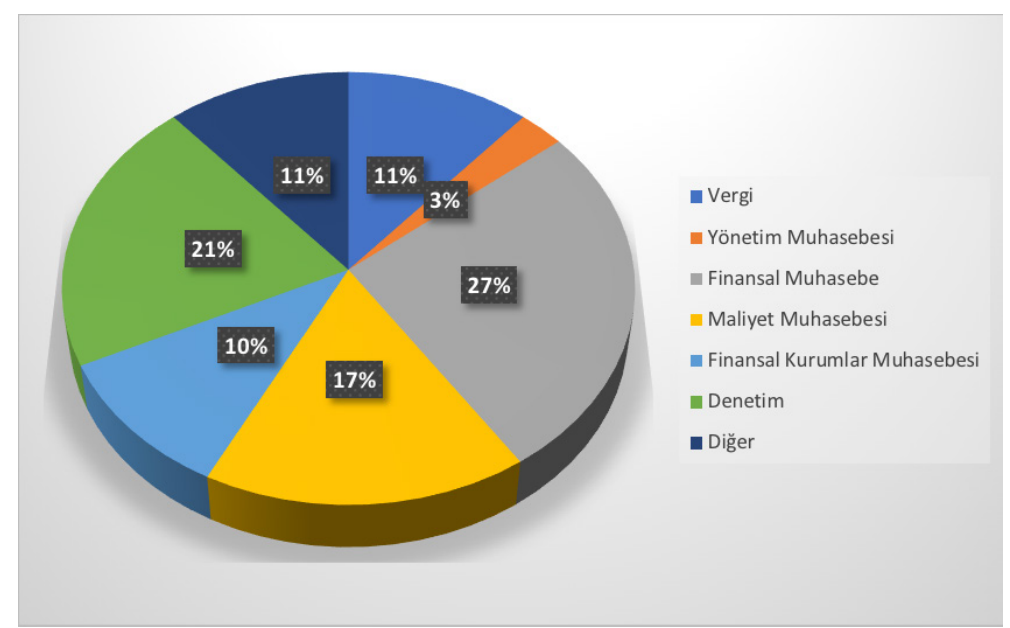

Şekil 7. 2004-2018 Yılları Arasında Yazılmış Yüksek Lisans ve Doktora Tezlerinde İncelenen Konuların Dağılımı

İncelenen 63 yüksek lisans tezinde en çok incelenen konuların finansal muhasebe ve maliyet muhasebesi olduğu görülmüştür. Hemen ardından, incelenme sıklığına göre, bu konuları vergi ve denetim konularının izlediğini söylemek mümkündür (Şekil 8). Finansal muhasebe ve maliyet muhasebesi konuları sırasıyla 15 ve 14 kez ele alınmıştır. Vergi konusu 11 kez ele alınırken denetim konusu ise 10 kez ele alınmıştır. 


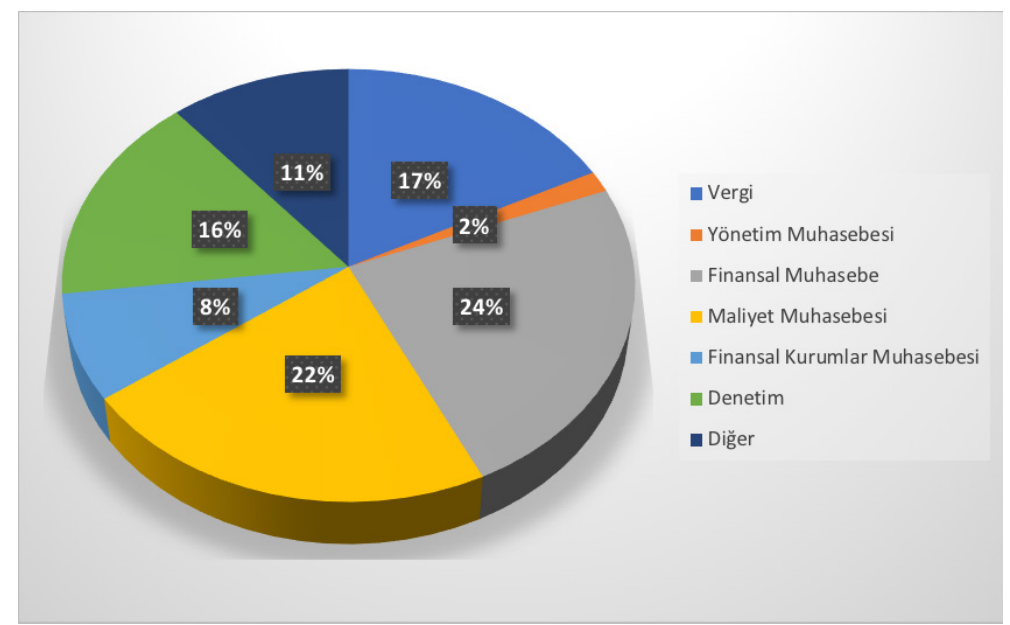

Şekil 8. 2004-2018 Yılları Arasında Yazılmış Yüksek Lisans Tezlerinde İncelenen Konuların Dağılımı

İncelenen 43 doktora tezinde ise en çok finansal muhasebe ve denetim konuları incelenmiştir. Bu konuların hemen ardından finansal kurumlar muhasebesi ve maliyet muhasebesi konuları sıklıkla çalışılmıştır (Şekil 9). Finansal muhasebe ve denetim konuları, sırasıyla, 13 kez ve 12 kez ele alınmış; finansal kurumlar muhasebesi ve maliyet muhasebesi konuları ise 6 kez ve 4 kez incelenmiştir.

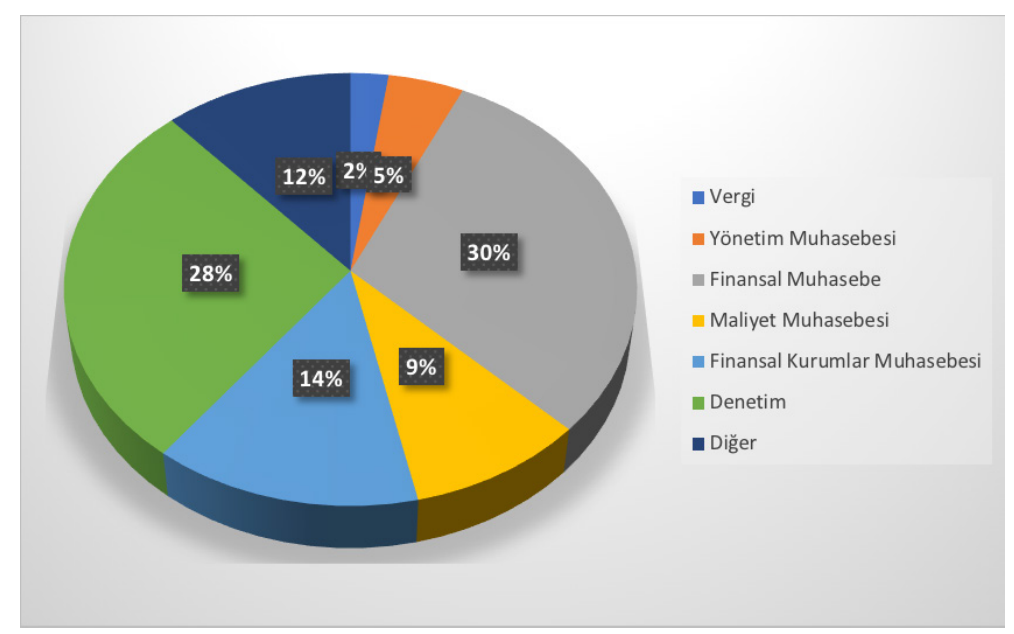

Şekil 9. 2004-2018 Yılları Arasında Yazılmış Doktora Tezlerinde İncelenen Konuların Dağılımı

\subsection{Metodoloji Açısından Bulgular}

Metodoloji açısından bulgular noktasında tez araştırmasının yapıldığı sektör, başvurulan araştırma tipleri ve kullanılan araştırma yöntemleri gibi hususlara yer verilmiştir.

İncelenen 106 tez, seçilen sektörler bazında incelendiğinde, tezlerin çoğunun tek bir sektörü kapsamadığı ve birden fazla sektör seçilerek araştırma yapıldı ğı görülmüştür. Tek sektör seçilerek yapılan araştırmalarda ise en çok İmalat, Finans ve Denetim sektörlerinin seçildiği görülmüştür. (Şekil 10). 


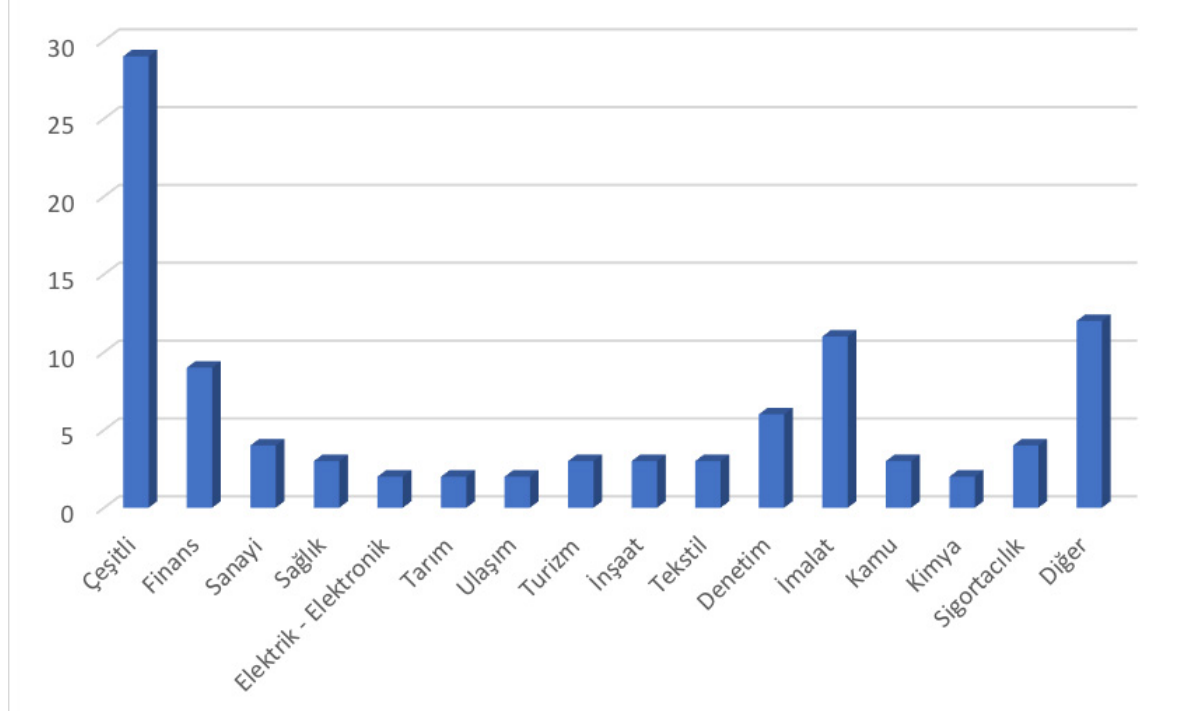

Şekil 10. 2004-2018 Yılları Arasında Yazılmış Tezlerin Araştırmalarının Yapıldığı Sektörlerin Dağılımı

Lisansüstü tezlerin çoğunluğunda birden fazla sektör seçilmiş olup, buna ek olarak, araştırmanın yapılmasında yüksek lisans tezlerinde en çok seçilmiş sektör imalatken doktora tezlerinde ise finansal sektördür. (Şekil 11).

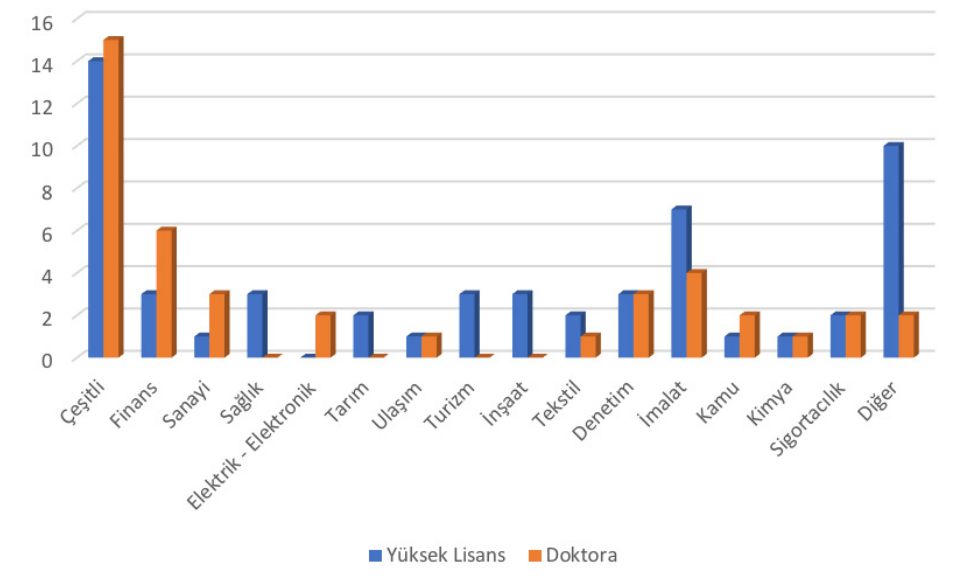

Şekil 11. 2004-2018 Yılları Arasında Yazılmış Yüksek Lisans ve Doktora Tezlerinin Araştırmalarının Yapıldığı Sektörlerin Dağılımı

İncelenen 106 tezde vaka metodu ile nicel ve nitel araştırmalar en çok kullanılan araştırma tiplerindendir. Seyrek olarak mukayeseli çalışmalar yapıldı̆̆ı saptanmıştır (Şekil 12). 


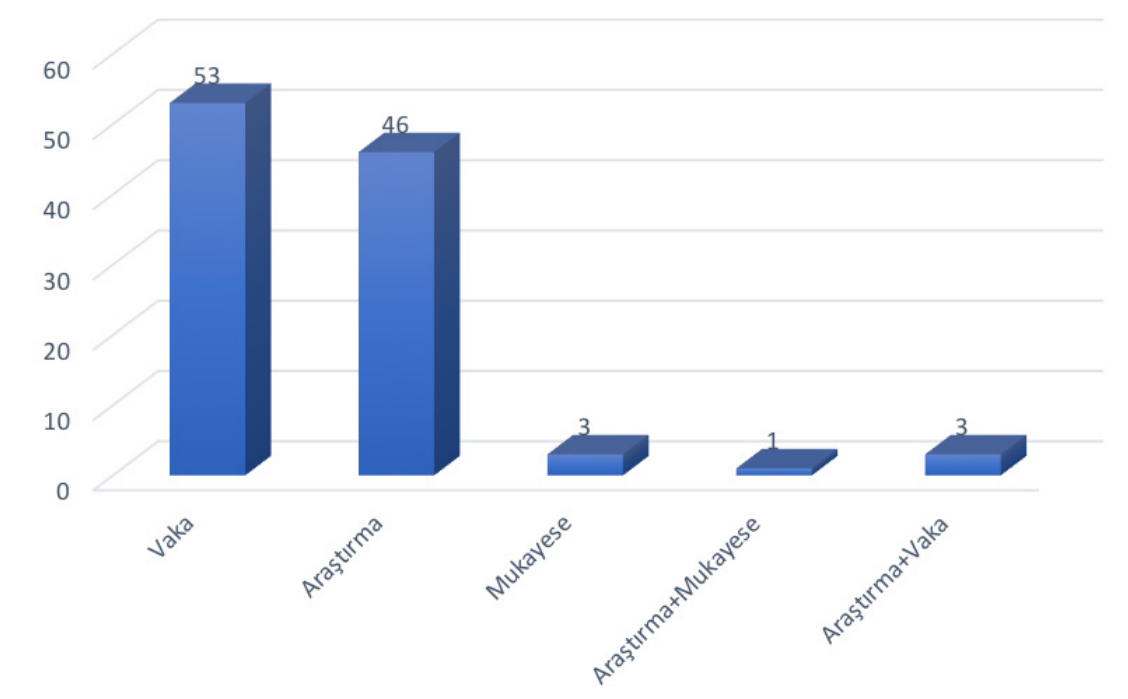

Şekil 12. 2004-2018 Yılları Arasında Yazılmış Tezlerde Kullanılan Araştırma Tiplerinin Dağılımı

Araştırma tiplerinin kullanımı bağlamında yüksek lisans tezlerinde vaka metoduna daha fazla başvurulurken, doktora tezlerinde ise nicel ve nitel araştırmalara daha fazla başvurulmuştur (Şekil 13).

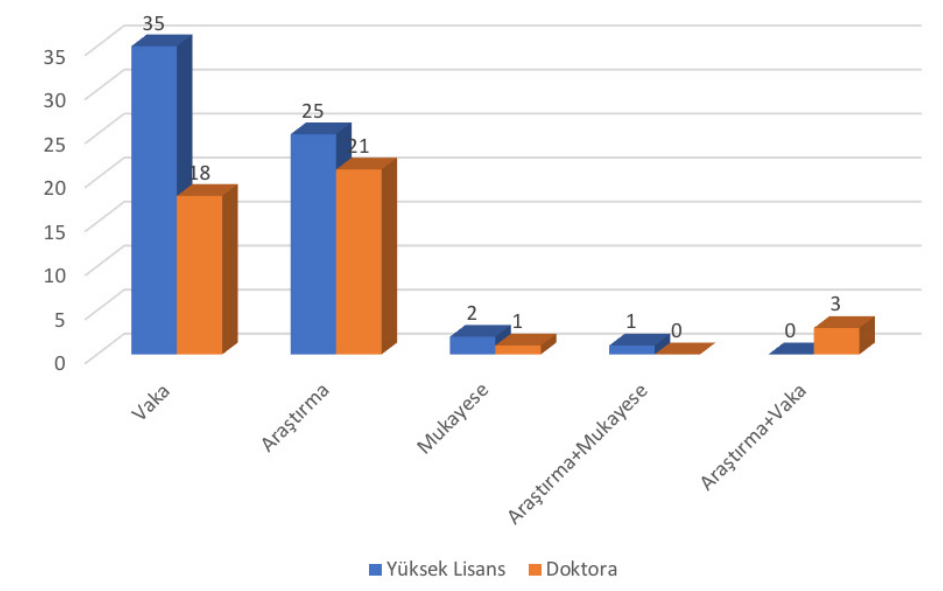

Şekil 13. 2004-2018 Yılları Arasında Yazılmış Yüksek Lisans ve Doktora Tezlerinde Kullanılan Araştırma Tiplerinin Dağılımı

Son 15 yılda yazılmış tezlerin çoğunluğunda nitel araştırma yönteminin kullanılmıştır (Şekil 14). 


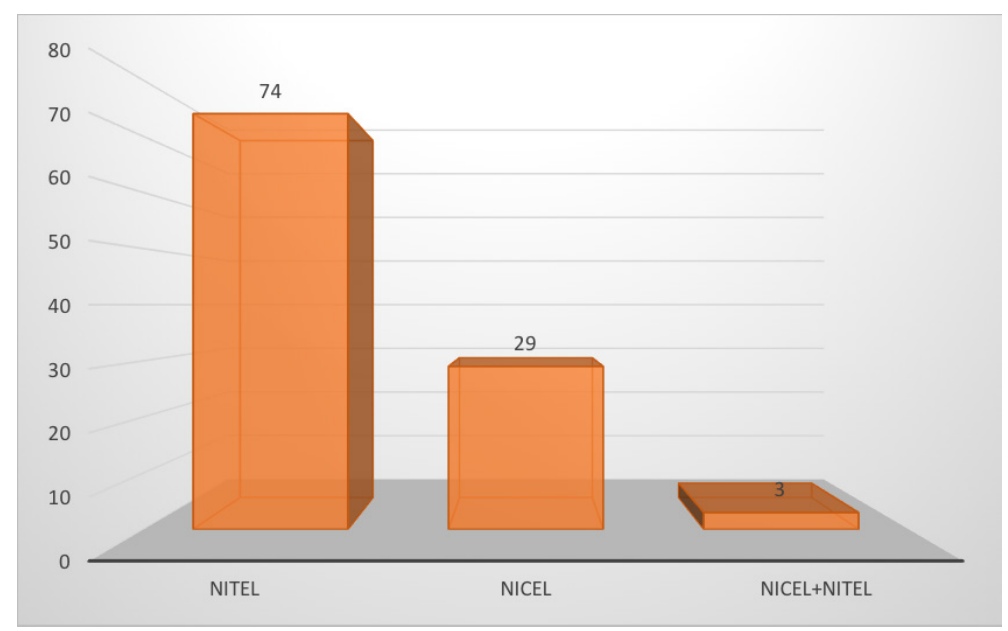

Şekil 14. 2004-2018 Yılları Arasında Yazılmış Tezlerde Kullanılan Araştırma Yöntemlerinin Dağılımı

Hem incelenen doktora tezlerinde hem de yüksek lisans tezlerinde çoğunlukla nitel araştırma yöntemleri kullanılmıştır (Şekil 15).

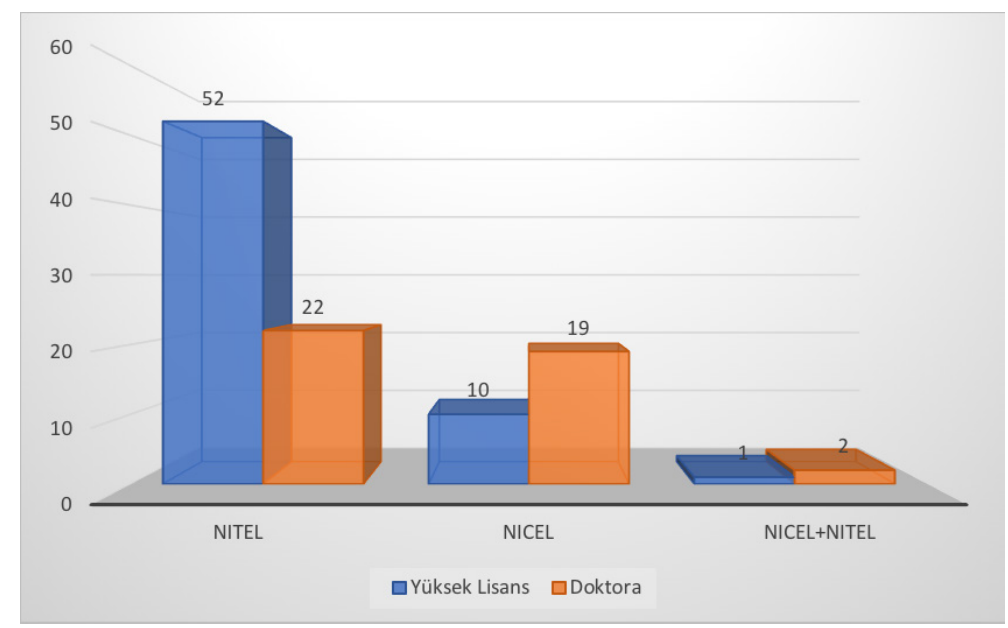

Şekil 15. 2004-2018 Yılları Arasında Yazılmış Yüksek Lisans ve Doktora Tezlerinde Kullanılan Araştırma Yöntemlerinin Dağılımı

\section{Araştırmanın Sonucu}

2004-2018 yılları arasında 106 tez tamamlanmış olup bunların 63'ü yüksek lisans teziyken, 43’ü ise doktora tezidir. Yıllar itibariyle tez sayıları ele alındığında 2014 yılında hiç yüksek lisans ve doktora tezi yazılmamışken, 2015 yılında hiç yüksek lisans tezi yazılmamıştır. En çok yüksek lisans tezi 11taneyle 2007 yılında yazılmışken, aynı yıl içerisinde yazılan en çok doktora tezi ise 7 taneyle 2010 y1lına aittir.

Lisansüstü tezleri, akademik danışmanlarının unvanları bağlamında incelendiğinde hem yüksek lisans tezlerinin hem doktora tezlerinin çoğunun profesör öğretim üyeleri tarafından yönetildiği gözlemlenmiştir. Yüksek lisans tezlerinin \%61,90'ı profesör öğretim üyeleri danışmanlığında yönetilirken doktora tezlerinin de \%81,39'u profesör öğretim üyeleri danı̧̧manlığında yönetilmiştir. Yüksek lisans tezlerinin \%26,98'i doçent öğretim üyeleri tarafından yönetilmiş, \%11,11'i ise yardımcı doçent öğretim üyeleri tarafından yönetilmiştir. Doktora tezlerinin hiçbiri yardımcı doçent öğretim üyeleri tarafından yönetilmemişken, \%18,60’ı ise doçent öğretim üyeleri tarafından yönetilmiştir. 
İlgili lisansüstü tezleri sayfa sayısı bakımından ele alındığında ise yüksek lisans tezlerinin ortalama 156 sayfa, doktora tezlerinin ise 256 sayfa olduğu söylenebilir. İncelenen yüksek lisans tezlerinin yarıdan fazlası $(\% 55,55)$ 101-150 sayfa aralığındayken, doktora tezlerinin ise yarıdan fazlası (\%53,49)201-300 sayfa aralığındadır. Sadece yazılmış olan 6 yüksek lisans tezi 100 sayfadan kısayken, doktora tezlerinin ise sadece 3’ü 400 sayfadan fazladır.

Lisansüstü tezlerin konuları incelendiğinde üzerinde en çok çalışma yapılmış konu finansal muhasebedir(28). Finansal muhasebeden sonra en çok çalışma yapılmış konu denetimdir(22). Bu iki konu, toplam yazılmış tezlerin \%47,16’sını oluşturmaktadır. Bu iki konuyu takip eden diğer konular ise sırasıyla maliyet muhasebesi (18), vergi(12) ve finansal kurumlar muhasebesidir (11). Yönetim muhasebesi $3 \mathrm{kez}$, muhasebe tarihi ve sorumluluk muhasebesi konuları 2'şer kez çalışılmıştır. Birer kez çalışılan konular ise şu şekilde sıralanabilir: çevre muhasebesi, devlet muhasebesi, etik, kurumsal sosyal sorumluluk, muhasebe bilgi sistemi, muhasebe eğitimi, muhasebe sistemleri ve risk. En çok çalışma yapılmış olan bu 5 konunun alt konularının da analizi ihtiyacı doğmuştur. Yapılan analiz sonucunda aşağıdaki sonuçlara varılmış ve konuya ilişkin detaylı tablo ise (Tablo 1) çalışmanın eklerinde sunulmuştur:

Metodolojik açıdan incelendiğinde, lisansüstü tezlerinin yazarları araştırmalarını yapacakları sektörü seçme noktasında hem yüksek lisans hem de doktora tezlerinde birden fazla sektöre ilişkin örneklere yer vermeyi tercih etmişlerdir (\%30,85). Yüksek lisans tezlerinin \%26,42'sinde, doktora tezlerinin ise \%36,59'unda araştırmalar çeşitli sektörlerde gerçekleştirilmişlerdir. Yüksek lisans tez araştırmalarının büyük çoğunluğu imalat sektöründe yapılmıştır $(\% 13,21)$. Bu sektörleri finans, sağlık, turizm, inşaat ve denetim sektörleri izlemiştir. Doktora tez araştırmalarının ise çoğunluğu finans sektöründe gerçekleştirilirken $(\% 14,63)$, bunu imalat, sanayi ve denetim sektörleri izlemiştir.

Lisansüstü tezlerinin araştırılması noktasında tez araştırmalarında başvurulan araştırma tiplerinin ve araştırma yöntemlerinin analiz edilmesi fayda sağlayacaktır. Tamamlanan 106 lisansüstü tezinin \%50'sinde vaka metodu kullanılmış olup (53 tez), \%43,40’ında ise nicel ve nitel araştırma yöntemlerine başvurulmuştur (46 tez). Tezlerin \%3,77'sinde ise bu araştırma tipleri birlikte kullanılmıştır Üç çalışmada ise mukayeseli araştırmalar yapılmıştır (ülkelerin muhasebe sistemlerinin karşılaştırılması vb.). Yüksek lisans tezlerinde 35 kez vaka metoduna, 25 kez nicel ve nitel araştırma yöntemlerine başvurulmuştur. Bu çalışmaların toplam yüksek lisans tezlerine oranı ise sırasıyla $\% 55,56$ ve $\% 39,68$ 'dir. Doktora tezlerinde ise $21 \mathrm{kez}$ nicel ve nitel araştırma yöntemlerinden (\%48,84), 18 kez ise vaka metodundan yararlanılmıştır $(\% 41,86)$.

Tamamlanan lisansüstü tezlerinde \%69,81'inde nitel araştırma yöntemlerine başvurulurken, \%27,36'sında nicel araştırma yöntemlerine başvurulmuştur. Tezlerin \%2,83'ünde ise nicel ve nitel araştırma yöntemleri beraber kullanılmışlardır. Yüksek lisans tezlerinin 52'sinde nitel araştırma yöntemlerine (\%82,54), 10'unda ise nicel araştırma yöntemlerine $(\% 15,87)$ başvurulmuştur. Bir tanesinde de hem nicel hem nitel araştırma yöntemleri beraber kullanılmıştır, Doktora tezlerinin de \%51,16'sında nitel araştırma yöntemlerine başvurulmuş olup (22 tez), \%44,19'unda ise nicel araştırma yöntemlerine başvurulmuştur (19 tez). İki tezde de hem nicel hem nitel araştırma yöntemleri beraber kullanılmıştır. Görüldüğü üzere yüksek lisans tezlerinde nitel araştırma yöntemlerinin kullanımı çok daha fazlayken, doktora tezlerinde bu dağılımın çok daha dengeli olduğu söylenebilir. Bu durum doktora tezlerinde nitel araştırmalarla elde edilen bulguların nicel çalışmalarla desteklenmesine ihtiyaç duyulduğunun bir göstergesi olarak da yorumlanabilir.

\section{Sonuç}

Bu çalışmada İstanbul Üniversitesi Sosyal Bilimler Enstitüsü Muhasebe Bilim Dalında tamamlanmış olan 106 yüksek lisans ve doktora tezi, bibliyometrik analiz yöntemiyle, incelenmiştir. Tezlere ilişkin incelemeler 15 yılı kapsamaktadır (2004-2018). Bu tezlerin incelenmesi sonucu elde edilen bulgular üç ana başlıkta ele alınmıştır.Bu başlıklar tanımlayıcı bulgular, içerik açısından bulgular ve metodoloji açısından bulgular olarak sıralanabilir. Tanımlayıcı bulgular yıllara göre tez sayıları, tez danışmanlarının akademik unvanları ve tezlerin sayfa sayılarından oluşmaktadır. İçerik açısından bulgular yıllara ve tez türlerine göre tez konularını içermekteyken metodoloji açısından bulgular ise tez araştırmalarının yapıldığı sektörlere ilişkin bilgilerden, tezlerde başvurulan araştırma tiplerinden ve araştırma yöntemlerinden oluşmaktadır. 
Finansal Muhasebe üzerine yazılmış tezler incelendiğinde en çok çalışma yapılan konunun Uluslararası Finansal Raporlama Standartları (UFRS) olduğu görülmüştür. Son 10 yılda UFRS’nin öneminin hızla artmasıyla birlikte, bu konuda çalışmalar artmış ve bu artış lisansüstü tezlerine de yansımıştır. UFRS hakkında yazılmış tezler incelendiğinde yazılan 10 UFRS konulu tezin 9'unun son 10 yılda yazılması da bu durumu doğrular niteliktedir.

Denetim üzerine yazılmış tezler incelendiğinde ise en çok çalışma yapılan konunun bağımsız denetim olduğu görülmüştür. Yaşanan muhasebe ve denetim skandallarıyla birlikte bağımsız denetimin önemi artmış ve bu durum denetim üzerine yazılmış lisansüstü tezlerinde bağımsız denetimin en popüler konu olmasına sebep olmuştur. Son yıllarda Türkiye’de Kamu Gözetim Kurumu'nun etkinliğiyle birlikte denetim skandalları neredeyse tarih olmuş ve gözler artık iyiden iyiye iç denetime çevrilmiştir

Maliyet muhasebesi üzerine yazılmış tezler incelendiğinde en çok çalışma yapılan konunun faaliyet tabanlı maliyetleme(FTM) olduğu görülmüştür fakat her ne kadar en çok çalışma yapılan konu olsa da faaliyet tabanlı maliyetlemenin git gide artık işlenmekten vazgeçilen konulardan biri olduğu da söylenebilir. Faaliyet tabanlı maliyetleme hakkında yazılan 6 tezden 4 ’ü 2004-2008 arası yazılmış ve bu konuda yazılan son tez 2015’te yazılmıştır.

Vergi üzerine yazılmış tezler incelendiğinde en çok çalışma yapılan konunun ertelenmiş vergi olduğu görülmüştür. Bu durum, ertelenmiş verginin 2000 ile 2010 yılları arasında çok tartışılıp, konuşulan bir konu olmasından kaynaklıdır. Ertelenmiş vergi, bu dönemde hem İstanbul Üniversitesi Sosyal Bilimler Estitüsü’nde hem diğer üniversitelerin hukuktan bağımsız olan yüksek lisans ve doktora programlarında en çok işlenen vergi konularından biri olmuştur. Günümüzde ise asıl odak artık ertelenmiş vergi değil transfer fiyatlaması, KDV ve kurumlar vergisi olmuştur.

Finansal kurumlar muhasebesi üzerine yazılmış tezler incelendiğinde birden çok aynı sayıda çalışmanın yapıldığ görülmüştür. Ekte sunulan tabloda (Tablo 1) Basel konusu sembol olarak gözükse de yine aynı sayıda sigortacılık ve vadeli işlem sözleşmeleri konuları üzerine tezler yazılmıştır.

Son olarak, bu çalışmada muhasebe alanında son 15 yılda ortaya konulmuş olan lisansüstü tezlerinin çeşitli kriterler bağlamında incelenmesi amaçlanmıştır. Belirlenen kriterler nezdinde erişilen tezlerden elde edilmiş olan sonuçlar tanımlayıcı bulgular, içerik açısından bulgular ve metodolojik açıdan bulgular olmak üzere üç ana başlıkta sınıflanmıştır. Tezlerin incelenmesi sürecinde sorgulayıcı ve tarafsız bir bakış açısını benimsemeye özen gösterilmiş; bu çalışmanın hem lisansüstü tez danışmanlarına hem de lisansüstü öğrencilerine, ilgili konuda fikir vererek, fayda sağlaması amaçlanmıştır.

Hakem Değerlendirmesi: Dı̣s bağımsız.

Çıkar Çatışması: Yazar çıkar çatışması bildirmemiştir.

Finansal Destek: Yazar bu çalışma için finansal destek almadığını beyan etmiştir.

Peer-review: Externally peer-reviewed.

Conflict of Interest: The author has no conflict of interest to declare.

Grant Support: The author declared that this study has received no financial support.

\section{Kaynakça}

Altıntaş, T. (2011). Uluslararası muhasebe ve Türkiye'de muhasebe hukuku. Sosyal Bilimler Dergisi, 1, 162-174.

Kavut, L., Adiloğlu, B. ve Baloğlu, G. (2017). Türkiye'de iç denetim üzerine yapılan akademik çalışmalar: 2010-2015 analizi. İstanbul: Türkiye İç Denetim Enstitüsü Yayınları.

Pekdemir, I., Erdoğan, U., Şen, Y. ve Yeke, S. (2015). “Yönetim ve organizasyon” alanında bir bilim dalında 2004-2015 yılları arasında yönetilmiş lisansüstü tezlerin incelenmesi. Istanbul Üniversitesi İsletme Fakültesi Işletme İktisadı Enstitüsü Yönetim Dergisi, 26(79), 20-56.

Sarı, E. ve Güngör, N. (2018). Türkiye'de katılım bankacılığı alanında hazırlanmış lisansüstü Çalışmalar: Bir literatür incelemesi. Üçüncü Sektör Sosyal Ekonomi Dergisi, 53(3), 1313-1322. 


\section{Ek Tablolar ve Şekiller}

Tablo 1: 2004-2018 Yılları Arasında Yazılmış Yüksek Lisans ve Doktora Tezlerinde İncelenen Konular

\begin{tabular}{|l|c|l|}
\hline Konular & Tez Sayısı & En Çok Çalışma Yapılan Alt Konular \\
\hline Finansal Muhasebe & 28 & UFRS (10) \\
\hline Denetim & 22 & Bağımsız Denetim (9) \\
\hline Maliyet Muhasebesi & 18 & Faaliyet Tabanlı Maliyetleme (6) \\
\hline Vergi & 12 & Ertelenmiş Vergi (4) \\
\hline FinansalKurumlarMuhasebesi & 11 & Basel (2) \\
\hline Yönetim Muhasebesi & 2 & \\
\hline Muhasebe Tarihi & 2 & \\
\hline Sorumluluk Muhasebesi & 1 & \\
\hline Çevre Muhasebesi & 1 & \\
\hline Devlet Muhasebesi & 1 & \\
\hline Etik & 1 & \\
\hline Kurumsal Sosyal Sorumluluk & 1 & \\
\hline Muhasebe Bilgi Sistemi & 1 & \\
\hline Muhasebe Eğitimi & 1 & \\
\hline Muhasebe Sistemleri & 1 & \\
\hline Risk & & \\
\hline
\end{tabular}

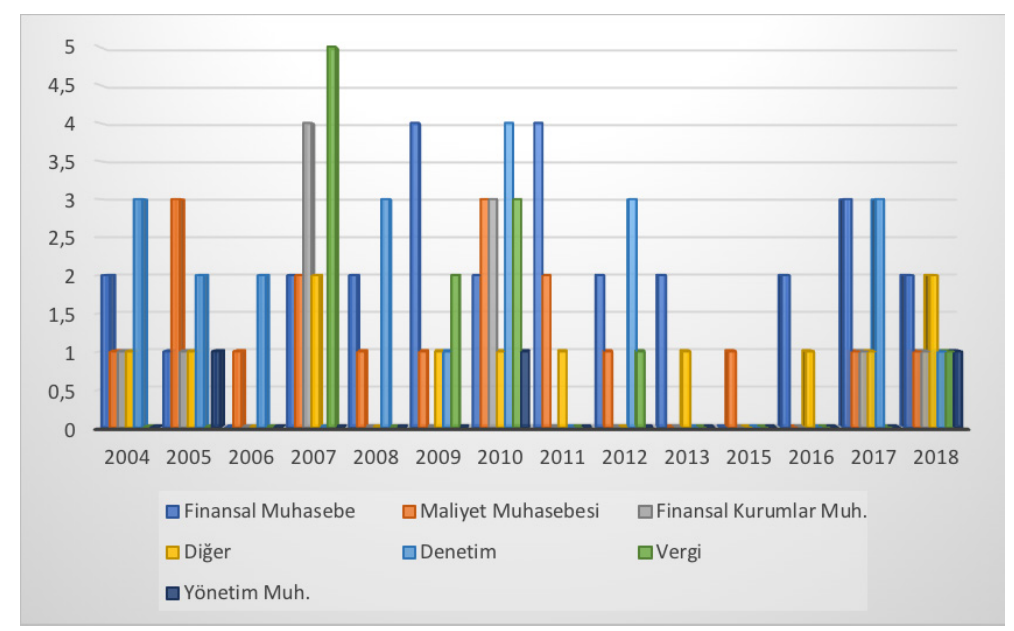

Şekil 16. 2004-2018 Yılları Arasında Yazılmış Yüksek Lisans ve Doktora Tezlerinde İncelenen Konuların Yıllara Göre Dağılımı 
